Reyneke RP

\title{
DIE BENUTTING VAN NARRATIEWE BEGINSELS TYDENS GEMEENSKAPSONTWIKKELING
}

\author{
Dr RP Reyneke, Departement Maatskaplike Werk, Universiteit Vrystaat, Bloemfontein.
}

\begin{abstract}
The main focus of this article is on the motivation of communities to become part of their own development. In order for development to take place, communities should be guided beyond their own negativity and helplessness. In doing this, attention is given amongst others to the constructivist paradigm, self-empowerment and underlying post-modern assumptions and principles of the narrative working method.
\end{abstract}

Although the narrative method is primarily used in therapy, the assumptions and principles are also applied in the context of community development. Practical strategies to be utilised during the application of narrative principles are discussed and the value of this working method described.

\section{INLEIDING}

Wanneer maatskaplike werkers bydraes tot kliënte se selfbemagtiging wil lewer, behoort kliënte geleenthede gebied te word om beheer oor hul situasie te verkry en verantwoordelikheid daarvoor te aanvaar. Kliënte kan sodoende hulself binne hul leefwêreld bevoordeel. In die proses kan kliënte hulself meesters van hul situasies maak deurdat hulle toegerus word met toepaslike kennis, vaardigheid en positiewe ingesteldhede (emosionele beheer) ten opsigte van hul situasies. Die gemeenskapsontwikkelaar behoort derhalwe aandag te gee aan kennis en vaardighede wat nodig is om byvoorbeeld 'n steenmakery te begin en te bestuur, maar behoort terselfdertyd kliënte in staat te stel om hul eiewaarde te verbeter (Reyneke, 2000:21). Die implikasie is 'n holistiese benadering, naamlik dat daar nie net aandag aan fisiese ontwikkeling gegee word nie, maar ook aan die psigiese en emosionele ontwikkeling van kliëntesisteme (individue, groepe en gemeenskappe) wat binne die opset van gemeenskapsontwikkeling tot selfbemagtiging begelei word.

Bemagtiging word deur Van Niekerk (1999:27) beskou as 'n aksie bestaande uit drie komponente, naamlik vaardighede, motivering en geleentheid. Vaardighede verwys na dít wat mense kan aanleer en wat hulle talente versterk en komplementeer. Motivering is energie wat mense dryf en tot doelbereiking trek. Hierdie twee komponente kry betekenis wanneer mense die geleentheid gegun word om te presteer. Indien die maatskaplike werker tot kliënte se selfbemagtiging wil bydra, behoort al drie aspekte derhalwe aandag te geniet (Reyneke, 2000:21).

Die fokus in hierdie artikel is op die een aspek wat dikwels in gemeenskapsontwikkelingsprojekte afgeskeep of oor die hoof gesien word, naamlik motivering van kliënte om by hulself en hul ontwikkeling betrokke te raak. Tydens 'n gemeenskapsvergadering wat gedurende 1999 gefasiliteer is, is die behoefte aan 'n kleuterskool byvoorbeeld deur 'n gemeenskap geartikuleer. Aangesien borgskappe vir lone moeilik bekom word, is die gemeenskapslede wat aanwesig was, gevra of die gemeenskap bereid sou wees om die arbeid gratis te verrig indien die nodige materiaal vir die bou van 'n kleuterskool bekom sou word. Die gemeenskapsreaksie was negatief, aangesien hulle op vergoeding aangedring het. Hierdie gemeenskap, soos baie ander, was nie bereid om by hul eie ontwikkeling betrokke te rak nie. Indien hulle nie self beloning ontvang nie, wil dit 
voorkom asof hulle belangstelling taan. Die redenasie is dat hulle arm is en op vergoeding geregtig is. Motivering om by selfontwikkeling en die ontwikkeling van hul gemeenskap betrokke te raak, is derhalwe in eksterne faktore gesoek.

Ontwikkelingstrategieë wat bloot op ekonomiese ontwikkeling of basiese behoeftebevrediging fokus, is dikwels onsuksesvol (Midgley, 1996:4-5). Ten einde ontwikkeling te bevorder, is dit nodig om gemeenskappe verby hulle eie negatiwiteit en hulpeloosheid te begelei. 'n Moontlike strategie wat benut kan word, is die narratiewe werkswyse. Die werkswyse spruit voort uit konstruktivistiese denke, en spesifiek uit die sosiaal-konstruktivisme (Dickerson en Zimmerman, 1996:80). Konstruktivistiese denke is in die postmodernistiese epistemologie gewortel (Janse van Rensburg, 2000:50).

Ten einde 'n begrip van hierdie werkswyse te vorm, word aandag geskenk aan konstruktivisme as paradigma, selfbemagtiging, postmodernistiese uitgangspunte onderliggend aan die narratiewe werkswyse, die omskrywing van die begrip narratief, kenmerke van stories en die beginsels onderliggend aan die narratiewe werkswyse. Telkens word vermeld hoe dit beslag vind binne gemeenskapsontwikkeling en kliënte se selfbemagtiging, met spesifieke klem op kliënte se motivering tot selfontwikkeling en tot dié van hulle gemeenskappe.

\section{KONSTRUKTIVISME EN SELFBEMAGTIGING}

Aangesien die uitgangspunte van die konstruktivisme 'n belangrike deel van selfbemagtiging uitmaak, word van die kernelemente van die radikale konstruktivisme, asook die sosiale konstruktivisme, kortliks vermeld. Volgens Shaw (1996:177) en Greene, Jensen en Jones (1996:173) is die volgende belangrike elemente:

- Die lewenservarings van mense bepaal die skepping van hulle wêrelde.

- 'n Mens gebruik kognisie vir werklikheidskepping.

- Kennis word nie ekstern bekom nie, maar ontwikkel deur interne kognitiewe prosesse.

Die sosiale konstruktivisme handhaaf in wese dieselfde uitgangspunte as die radikale konstruktivisme, met dié verskil dat eersgenoemde van mening is dat kennis ekstern deur interaksie met die omgewing gekonstrueer word. Kennis word dus nie beskou as die resultaat van slegs interne prosesse nie.

Vanuit bogenoemde blyk dit dat kennis ekstern deur middel van interaksie en taal gekonstrueer word, maar dat interne prosesse ook plaasvind wanneer die mens hierdie inligting analiseer en internaliseer. Tereg is dit dus "... not the events in our lives that shape us, but our beliefs as to what those events mean" (Robbins, 1992:73). Invloede uit die omgewing speel dus 'n rol in kliënte se sienings van die werklikheid. So kan een persoon wat byvoorbeeld 'n been tydens ' $n$ ongeluk verloor, dit nie as 'n kruis sien nie en in sportaktiwiteite uitblink, terwyl 'n ander hom-/haarself kan bejammer en die passiewe slagoffer van die situasie kan wees. Interne betekenisgewingsprosesse bepaal dus wat persone met situasies mak en wat die invloed van situasies op hulle funksionering is.

Ander elemente van die konstruktivisme wat by bogenoemde aansluit, is volgens Von Glassersfeld (1984:27-29 en 1995:18, 51); Magadla (1996:83-85), Zietsman (1996:72) en Du Plessis en Ferreira (2000:23-24) die volgende:

- Kennis wat 'n mens benut, is dit wat jy as bruikbaar vir jouself evalueer, ongeag wat ander daarvan maak. 
- Die mens gee uiting aan sy werklikheid deur kommunikasie en die benutting van taal.

- Werklikheidskepping is 'n voortdurende, dinamiese proses.

- 'n Objektiewe werklikheid bestaan nie binne die werklikheidskepping van die individu nie.

Elemente van die konstruktivisme maak deel uit van die basiese uitgangspunte van die narratiewe benadering. In dié verband sê Freedman en Combs (1996:22) tereg dat "... it is more important to approach people and their problems with attitudes supported by these ideas than it is to use any particular narrative technique". Die paradigma, eerder as spesifieke narratiewe tegnieke, behoort dus die gemeenskapsontwikkelaar tydens dienslewering aan die gemeenskap te rig.

Effektiewe kommunikasie word as 'n integrerende deel van die gemeenskapsontwikkelingsproses beskou. Daardeur word mense tot die ontdekking van eiewaarde gelei, wat intrinsieke groei tot gevolg kan hê (Van der Berg, Collins \& O’Neil, 1999:113). Die uitgangspunt is dat indien effektiewe kommunikasie tussen die gemeenskapsontwikkelaar en die gemeenskap, maar ook tussen gemeenskapslede onderling plaasvind, dit daartoe kan lei dat hulle werklikheid so gekonstrueer word dat dit die ontdekking en ontginning van die hele gemeenskap se eiewaarde tot gevolg het. Verbeterde eiewaarde kan lei tot selfhelp en groter motivering om aan ontwikkelingsprogramme deel te neem.

\section{POSTMODERNISTIESE UITGANGSPUNTE ONDERLIGGEND AAN DIE NARRATIEWE WERKSWYSE}

Narratiewe terapie is vir postmodernisme wat psigoanalise vir modernisme is (Parry \& Doan, 1994:6). Die filosofie van taal is 'n fundamentele element van die postmodernisme. Taal word as 'n metafoor vir die lewe beskou. Die betekenis van woorde is nooit vas nie, want die vertolking van teks hou verband met die konteks waarbinne dit geskryf is. Die teks van die lewe is derhalwe in 'n konstante proses van verandering. Die lewe moet dus vertolk word, aangesien daar geen vaste waarhede en waardes is nie (Janse van Rensburg, 2000:6). Hoewel vanuit 'n Christelike perspektief nie daarmee akkoord gegaan word dat daar geen vaste waarhede en waardes bestaan nie, het die postmodernisme sekere elemente, veral die oorweging dat alles nie wit of swart is nie, aanvaar. Die narratiewe werkswyse, wat sy oorsprong in die filosofie van die postmodernisme het, maak veral van taalkonstruktivisme gebruik (Van der Berg et al., 1999:117), naamlik deur taal te gebruik om 'n ryker beskrywing van mense se werklikheid te gee. Die strewe is om kliëntestelsels in staat te stel om die werklikheid so te herkonstrueer dat dit tot selfbemagtiging sal bydra.

Kennis van enkele basiese beginsels wat uit die postmodernisme voortspruit, is derhalwe noodsaaklik wanneer narratiewe tegnieke tydens gemeenskapsbegeleiding tot selfbemagtiging benut word. Ter aanvulling is kennis van die algemene beginsels van die postmodernisme noodsaaklik. Hierdie beginsels word vervolgens kortliks genoem en beskryf.

\section{Werklikheid is sosiaal gekonstrueer}

'n Sentrale tema van die postmodernisme is dat gelowe, wette, sosiale en algemene gebruike ten opsigte van byvoorbeeld kleredrag en voedsel, die resultaat is van jarelange sosiale interaksie. Mense konstrueer hulle eie werklikhede terwyl hulle besig is om dit uit te leef. Dit beteken dat die voorbeeld wat deur byvoorbeeld gesinne, families, vriende en onderwysers, gestel word as dié waarheid aanvaar word (Freedman en Combs, 1996:25). Die konstruering van eie narratiewe vind dus tydens sosiale interaksie plaas. Internalisering van die sosiale werklikheid vind plaas en word deel van die individu se persoonlike werklikheid. Alhoewel die mens se werklikheid sosiaal 
gekonstrueer word, is dit primêr die resultaat van betekenisgewing deur elke individu (Robbins, 1992:74 en Burck en Daniel, 1995:31).

Persoonlike interpretasies van die werklikheid wat deur andere geskep word, beïnvloed derhalwe kliëntesisteme deurdat dit, onder andere, bepaal wat kliënte se sienings van hulleself en andere tans is en in die toekoms sal wees. Voorts impliseer dit dat indien 'n andersoortige werklikheid geskep word, hierdie nuwe werklikheid later deur die groter groep aanvaar sou kon word, juis aangesien werklikheid sosiaal gekonstrueer word.

\section{Werklikheid word geskep deur taal}

Vanuit 'n modernistiese denkraamwerk word gemeenskapsverhoudings deur die intellek/wetenskap bepaal. Die postmodernisme bevraagteken egter die mag van beredenering. Die standpunt is dat beredenering as sulks nie verhoudings beïnvloed nie, maar dat taal 'n beïnvloedende rol speel. Taal beskryf die gekonstrueerde verhoudings tussen mense en van gemeenskappe. Verskillende betekenisse wat aan woorde geheg word, is 'n uitdrukking van voorneme, ervaring en narratiewe in die gemeenskap en is bepalend vir die aard en intensiteit van verhoudings. Die filosoof Ferdinand de Saussure redeneer dat taal nie neutraal is nie, maar binne ' $n$ spesifieke verhouding staan. Vir hom is taal eerder 'n simboliese sisteem waarvan die betekenis binne 'n verhouding van verskil gegenereer word. Dit bring mee dat taal 'n vorm van aktiewe en sosiale mag is. Die betekenis wat aan woorde gegee word, is relatief tot die gebruiker se bedoeling en die konteks waarin dit gebruik word. Taal wat benut word, dui die werklikheid van die kliëntesisteem aan (Loevlie, 1992:124; Seidman, 1994:196-197; Janse van Rensburg, 2000:15-16).

Vir gemeenskapsontwikkelaars is die implikasie dat wanneer met kliëntesisteme gekommunikeer word, sorg gedra moet word om werklik te verstaan wat gesê word. As gemeenskapslede byvoorbeeld sê dat hulle honger is, sou dit 'n behoefte aan voedsel, maar moontlik ook 'n smag na kennis kan impliseer. Gemeenskapsontwikkelaars behoort dus te fokus op die betekenis van werklikhede wat kliëntesisteme deur taal kommunikeer.

\section{Werklikheid word georganiseer en onderhou deur stories}

Die mening van White en Denborough (1998:3) is dat narratiewe werkswyses gebaseer is op "... the idea that people's lives and relationships are shaped by the 'stories' which individuals and communities of people develop in order to give meaning to their experiences. These 'narratives of meaning' do not simply reflect or represent our lives - they actually shape and constitute our lives." Mense se lewenstories bevat dus hulle ervarings en belewenisse, maar dit sou ook onbenutte geleenthede kon openbaar. Van der Berg et al. (1999:118) is van mening dat laasgenoemde veral tydens gemeenskapswerk van toepassing is. Wanneer gemeenskappe hulle stories vertel, blyk dit dikwels dat groeipotensiaal en onderbenutte geleenthede teenwoordig is. Die gemeenskap leef volgens die negatiewe manuskrip/draaiboek wat die lewe na hulle mening vir hulle geskryf het. Hulle het dit in werklikheid egter vir hulself geskryf. Vir verandering in mense se lewens moet hulle stories dus verander. Hulle narratiewe/verhale behoort so te verander dat ' $n$ nuwe, meer funksionele en lewegewende werklikheid geskep word.

Die gemeenskapsontwikkelaar kan dus 'n bydrae lewer tot gemeenskappe se selfbemagtiging deur nuwe betekenisgewing aan hulle situasie te fasiliteer. Die werklikhede wat sodoende geskep word, behoort van so ' $n$ aard te wees dat dit sal help met die vind van 'n oplossing vir problematiese situasies wat ervaar word (Du Plessis \& Ferreira, 2000:37). Vanuit 'n Christelike epistemologie sal die nuwe manuskrip aan die algemeen geldende norme en waardes van die gemeenskap voldoen. Dit beteken dat 'n maatskaplike werker met onaanvaarbare gedrag kan handel en dit probeer 
verander, aangesien van die standpunt uitgegaan word dat grootse vertellings ${ }^{1}$ (grand narratives) bestaan (Janse van Rensburg, 2000:7).

Aangesien mense se werklikhede deur stories gevorm en in stand gehou word, kan gemeenskappe se stories derhalwe aangewend word om hulle nuut na hulself en hul omgewing te laat kyk. Nuwe, opbouende stories van hoop behoort dus tot positiewe eiewaarde te lei, waardeur ontwikkeling en selfbemagtiging bevorder kan word.

\section{Essensiële waarhede bestaan nie}

Die postmodernisme gaan van die standpunt uit dat daar geen essensiële waarheid bestaan nie. Dit bring mee dat enige objektiewe outoriteit, die Bybel ingesluit, deur die postmodernisme verwerp word (Janse van Rensburg, 2000:45). Hierdie uitgangspunt gee daartoe aanleiding dat die postmodernisme in totaliteit onaanvaarbaar vir byvoorbeeld die Christengeloof is. Tog kan akkoord gegaan word met die standpunt dat die narratiewe/betekenisgewing waaraan kliënte vasklou, kan verander en dat daar vir kliënte nie essensiële waarhede binne die konteks van hul situasie bestaan nie.

Volgens Du Plessis en Ferreira (2000:35) het elke mens sy eie werklikheidskepping ten opsigte van die gesin waarin hy leef. 'n Eie interpretasie is dat elkeen ook sy eie werklikheidskepping toepas met betrekking tot breër sisteme waarbinne hy funksioneer, byvoorbeeld ten opsigte van die gemeenskap waarvan hy 'n lid is. Tereg wys Dean (1993:134-135) daarop dat essensiële waarhede nie in gemeenskapslede se interpretasie van hul gemeenskapsgeskiedenis bestaan nie. Gemeenskappe verskaf in hul geskiedenisbeskrywings 'n rekonstruksie, herinterpretasie en herformulering van hul herinneringe aan gebeure. Hierdie beskrywings dui egter nie noodwendig op historiese waarhede nie, want narratiewe oor gebeure verander met verloop van tyd en word beïnvloed deur die konteks waarin dit vertel word. Faktore wat die unieke werklikheidskepping van kliëntesisteme beïnvloed is onder andere die betrokkenheid van die maatskaplike werker, kultuur, godsdiens en historiese oorlewerings in die gemeenskap.

Aangesien elke individu 'n eie werklikheid het en dit kan verander wanneer 'n ander persoon se werklikheid daarmee gekombineer word, blyk dit dat een essensiële werklikheid nie bestaan nie. Elke mens het dus sy eie waarhede en/of wyses waarop die werklikheid gesien en geïnterpreteer word. Hierdie werklikheidskepping vind egter plaas binne 'n konteks van grootse vertellings (grand narratives) (Janse van Rensburg, 2000:7), wat algemeen geldende waardes, norme en wetgewing wat gedrag rig, sou kon insluit. Kliënte kan hul betekenisgewing tot voordeel van hulself en die gemeenskap verander, met die voorvereiste dat voortspruitende gedrag binne die breër konteks aanvaarbaar moet wees.

Alhoewel die postmodernisme in die geheel nie deur Christene aanvaar kan word nie, is dit moontlik om van postmodernistiese strategieë gebruik te maak sonder om dit binne die postmodernistiese epistemologie te plaas. Hierdie strategieë kan binne 'n Christelike paradigma geplaas word, wat daarop neerkom dat toepaslike postmodernistiese strategieë binne algemeen geldende Bybelse waardes en norme geïdentifiseer en uitgeleef kan word.

\section{OMSKRYWING VAN DIE BEGRIP NARRATIEF}

Die benutting van narratiewe is een van die strategieë van die postmodernisme. Janse van Rensburg (2000:37) wys daarop dat dié strategie nie eksklusief tot die postmodernistiese

Die term verwys na die bestaan van sekere algemeen geldende waarhede wat vas staan. 'n Voorbeeld hiervan is byvoorbeeld die Bybel wat as die Woord van God gesien word. Die waarhede wat daarin staan, is vir die Christen vas en onveranderbaar. 
paradigma is nie. In die Bybel word ook van narratiewe gebruik gemaak, byvoorbeeld waar Jesus 'n dekonstruksie van die Samaritaanse vrou se narratief doen (in Johannes 4). Hy verander haar betekenisgewing aan hulle gesprek só dat sy tot insig gebring word dat Hy die Verlosser is.

Volgens Neal (1996:66) kan 'n narratief verstaan word as die bevatlikheid (frame of intelligibility) wat mense benut om die werklikheid te interpreteer. Aangesien taal en denke met kulturele oortuigings deurspek is, is die effek van narratiewe nooit neutraal nie. As gevolg daarvan kan narratiewe sommige mense bemagtig en andere terselfdertyd ontmagtig. Narratiewe het dus 'n betekenisvolle invloed op die lewens van kliëntesisteme. Dat 'n narratief oor die vermoë beskik om mense te ontmagtig, dui moontlik daarop dat dit 'n invloed op die mens se interne motiveringspatrone kan hê. 'n Narratief kan ook omskryf word as 'n "... unit of meaning that provides a frame for lived experience. It is through these stories that lived experience is interpreted. We enter into stories; we are entered into stories by others; and we live our lives through these stories" (sien Epston, White \& Murray, 1992:97). Deur middel van stories poog mense dus om betekenis en doel aan die lewe te gee, en deur stories kan mense begelei word om 'n lewe te voer waarmee hulle tevrede is.

Sommige skrywers verwys na stories wanneer narratiewe ter sprake is. Holland en Kilpatrick (1993:302) benut byvoorbeeld deurentyd die term stories wanneer bespreking oor narratiewe tegnieke gevoer word. Ander skrywers soos Sluzki (1992:218), Dean (1993:291) en Mortola (1999:3) gebruik die terme as sinonieme. Du Plessis (2000:101) is van mening dat daar nie 'n wesenlike verskil tussen die twee begrippe is nie, maar dat wanneer die term narratief benut word, gewoonlik na die breë denke en gedagtegange van die narratiewe benadering verwys word. Die term "stories" word benut wanneer na vertellings van mense se lewenservarings verwys word.

Vir gemeenskapsontwikkelaars is die implikasie dus dat gemeenskapslede se rekonstruksie van en herinneringe aan gebeure hulle betekenisgewing aan hulself en hul gemeenskap sal bepaal. Indien die betekenisgewing positief is, sal hulle waarskynlik positief oor hulself en hul gemeenskap voel. Ervarings wat tot betekenisgewing van byvoorbeeld oorwinning of sukses lei, kan moontlik tot gevolg hê dat vraagstukke in die gemeenskap nie meer as probleme geïnterpreteer word nie, maar as uitdagings. Wanneer dekonstruksie van stories gedoen word, moet daar derhalwe veral aandag aan positiewe betekenisgewing geskenk te word.

\section{KENMERKE VAN STORIES}

Stories maak 'n belangrike deel uit van mense se beskrywing van lewenservarings, aangesien mense hulle lewensgeskiedenis aan die hand van 'n eie storie organiseer (self-narrative) (Jankowski, 1998:111). Sulke stories is waarskynlik wyses waarop mense hulle ervarings en gevoelens aan ander oordra en dit in die proses vir hulself interpreteer. Ter verduideliking van die konsep word kenmerke en eienskappe van stories kortliks toegelig.

'n Storie beskik volgens Mortola (1999:3) oor drie basiese elemente. Alle stories bestaan eerstens uit 'n element van toneelbeskrywing (scene setting), waartydens 'n verduideliking plaasvind van die normatiewe werklikheid, oftewel 'n ekwilibrium. Die volgende element is die beskrywing van kwelling (troubling), waar 'n verbreking van norme plaasvind, wat tot disekwilibrium lei. Laastens bevat stories 'n poging tot singewing (sense-making), waartydens 'n nuwe begrip van die werklikheid gekonstrueer word. 'n Gewysigde ekwilibrium word derhalwe geskep. Hieruit blyk dit dat daar deurentyd gepoog word om deur stories ekwilibrium met die omgewing te behou. Wanneer 'n gebeurtenis die ekwilibrium versteur, is dit nodig dat 'n nuwe werklikheid geskep word, waartydens die versteurde ekwilibrium herstel kan word. 'n Wysiging van die storie is dus nodig, sodat dit gelukkig kan eindig. 
Twee dimensies van stories word deur White (1993:36-37) onderskei, naamlik feitelike gebeure (landscape of action) en betekenisgewing (landscape of consciousness). Eersgenoemde, wat na die kronologiese verloop van die storie verwys, bestaan uit

- bepaalde gebeure;

- gebeure wat opeenvolg;

- gebeure wat oor tyd (verlede, hede en toekoms) saamgevoeg word; en

- 'n bepaalde tema.

Die betekenisgewing verwys na die karakters in die storie se interpretasies van gebeure. Die aanhoorder se betekenisgewing word hierby ingesluit. Volgens White (1993:37) en Du Plessis (2000:102) word hierdie dimensie gedomineer deur persepsies, denke, spekulasies en gevolgtrekkings wat deur die karakters oor die bepaalde gebeure gemaak word. Derhalwe word hierdie persepsies en gevolgtrekkings beïnvloed deur

- die begeertes en voorkeure van die karakters;

- die kenmerke en kwaliteit van hulle verhoudings;

- hul motiewe, oogmerke en waardes; en

- dit wat die karakters glo.

Hieruit blyk dit dat wanneer die verteller die storie vertel, daar sprake van feitelike gegewens is. Sodra die betrokkene egter algemene gevolgtrekkings en persepsies op die situasie van toepassing maak is feite nie meer ter sprake nie, maar wel betekenisgewing. Stories is dus 'n middel waardeur uitdrukking gegee word aan die belewenis van die werklikheid, na aanleiding van interpretasies daarvan.

'n Volgende kenmerk van stories is dat dit geleentheid vir die mens skep om ervarings aan 'n tydsdimensie te koppel. Stories konstrueer ' $n$ begin en 'n einde. Die verlede, hede en toekoms kry dus aandag (Epston, 1998:11). Die tydsdimensie laat ruimte vir interpretering van die verlede, en interpretasie van die verlede in die hede help met die daarstel van 'n toekomsvisie. Hierdie visie gee daartoe aanleiding dat mense binne nuwe stories wat in die hede geskep word, kan begin om 'n nuwe lewe in die toekoms te leef waarin hul selfkonsep beter is, daar nuwe moontlikhede vir verhoudings is en 'n nuwe toekoms geskep kan word (Freedman en Combs, 1996:16).

Die belang van hierdie konsep lê daarin dat mense in hulle verlede so vasgevang kan raak dat die hede en toekoms nie opgemerk word nie. Wat wel gebeur, is dat die verlede in die hede uitgeleef word, en dit dan as 'n aanwyser vir die toekoms dien (Ferreira en Botha, 1999:82). In hierdie verband noem Müller (1996:101) dat as die stories van die verlede en dié van die toekoms nie tot 'n sinvolle eenheid saamvloei nie, patologie teenwoordig is, omdat daar nie staanplek is waarop die toekomsstorie vorm kan aanneem nie. 'n Vae, onderontwikkelde toekomsstorie, of 'n helder maar onrealistiese droombeeld van die toekoms kan dus aanwesig wees.

Eie ervaring in die ontwikkelingsveld is dat kliëntesisteme dikwels so vasgevang is in hul huidige situasie, wat uit hulle verlede spruit, dat die toekoms as't ware nie vir hulle saak maak nie. Diegene is net ingestel op huidige oorlewing, want 'n toekomsstorie bestaan nie. Wanneer die maatskaplike werker binne die drie tydsdimensies werk, raak dit moontlik om die betrokkenes daarop te wys dat daar byvoorbeeld in die verlede gebeurtenisse was wat positief vir die hede is. Die gebeure behoort dus positief deur die kliëntesisteem herformuleer te word, sodat 'n nuwe storie vir die toekoms geskryf word. Dit wat uit die verlede geleer is, word benut vir die skep van 
'n nuwe toekoms. 'n Nuwe verhaal wat in die toekoms die kliënt tot selfbemagtiging in staat kan stel, moet ontwikkel word.

'n Storie verteenwoordig nie 'n individu se hele lewe nie, maar net daardie gedeelte wat op die voorgrond is. Die huidige storie is daardie gedeelte van sy lewe wat hy probeer uitpluis, met ander woorde, dit wat in disekwilibrium is (Mortola, 1999:7). In gevallestudies wat White en Denborough (1998:33-77) voorhou, is dit duidelik dat stories gewoonlik oor 'n probleemarea in mense se lewens handel, en nie oor hulle totale lewe nie. Wanneer die storie oorvertel of weer vertel word, word daar opnuut 'n storie geskep wat nie presies dieselfde is as die aanvanklike een nie. Gebeure sal nie weer presies dieselfde beskryf word nie en karakters in die storie sal byvoorbeeld in meer, of minder, detail bespreek word. Ervarings wat aan insidente gekoppel word, sal ook wat intensiteit en omvang betref vervorm word (White en Epston, 1990:13 en Du Plessis, 2000:103).

In stories is daar altyd karakters met onderlinge verhoudinge wat 'n rol in die hele verwikkelingsplan speel (Weingarten, 1998:13). Hierdie verhoudinge speel dus 'n rol in die kliënt se interpretasie van die storie. Sowel die dominansie van karakters as die betekenis wat die verteller aan elkeen gee, verskil telkens wanneer die storie vertel word (Parry, 1991:52; Gergen, 1994:191 en Du Plessis, 2000:103). Volgens Epston (1998:13-14) is "... all stories ... indeterminate. There is a degree of ambiguity and uncertainty to all stories, and, as well, there are inconsistencies and contradictions." Hierdie teenstrydighede kom voor aangesien geen enkele storie al die gebeure van die individu se lewe weergee nie. Die storieverteller benut 'n netwerk van stories om uitdrukking te gee aan sy lewe of fasette daarvan (Du Plessis, 2000:104). Die fasiliteerder ${ }^{2}$ kan deur middel van vraagstelling die gapings invul, ten einde ' $n$ volledige beeld van die storie te vorm.

Uit bostaande word afgelei dat deur die benutting van die kliënt se dominante storie en die verandering van 'n storie wat vir die kliënt problematies is, word gepoog om 'n ekwilibrium te skep, gekenmerk deur optimale maatskaplike funksionering. Robbins (1992:201) stel dit treffend dat: "... most beliefs are formed by words - and they can be changed by words as well." Die narratiewe werkswyse leen hom by uitstek daartoe om mense se sienings oor hulself te verander. Binne die konteks van gemeenskappe kan die werkswyse doeltreffend benut word om verandering te bewerkstellig, aangesien die gemeenskap tot die formulering van 'n realistiese toekomsvisie begelei word. 'n Voorvereiste is egter dat betekenisgewing aan verlede- en hedestories van so 'n aard moet wees dat dit 'n konteks vir selfbemagtiging skep, en nie vir ontmagtiging nie.

\section{BEGINSELS ONDERLIGGEND AAN DIE NARRATIEWE WERKSWYSE}

In Maatskaplike Werk is daar verskeie algemeen aanvaarde beginsels, byvoorbeeld erkenning, selfbeslissingsreg, eerbied en agting, aanvaarding, indiwidualisering, selfhelp, selfwerksaamheid en konfidensialiteit (Reyneke, 2000:57-59). 'n Analise van hierdie beginsels bring aan die lig dat almal voorkom in die beginsels onderliggend aan die narratiewe werkswyse. Hierdie beginsels komplementeer mekaar deurlopend. Die narratiewe werkswyse is dus in ooreenstemming met die werkswyses en filosofie van Maatskaplike Werk en gemeenskapsontwikkeling.

'n Idee van die onderliggende beginsels van 'n spesifieke werkswyse help die fasiliteerder met die implementering daarvan. Volgens Du Plessis (2000:132) onderskei skrywers oor narratiewe terapie selde tussen beginsels. Dit blyk egter dat 'n aantal beginsels rigtinggewend is vir hierdie terapie. Sodanige beginsels word kortliks toegelig.

2 'n Fasiliteerder is die persoon wat die proses van betekenisgewing by die kliënt vergemaklik (Hawkins, 1988:285). Hierdie term word afwisselend gebruik met maatskaplike werker, ontwikkelaar en gemeenskapsontwikkelaar. 


\section{Nie-kundige posisie}

'n Nie-kundige posisie wat die fasiliteerder tydens gesprekke met kliënte inneem, is belangrik tydens die hele proses van herinterpretasie en herstrukturering (Freedman \& Combs, 1996:44-45; Du Plessis, 2000:132 en Ferreira \& Botha, 1999:84). Tydens hulpverlening word gepoog om nuwe betekenis aan gebeure te gee. Die fasiliteerder en die kliënt weet nie wat hierdie nuwe betekenis is waarheen gewerk word nie, aangesien dit 'n proses van nuwe werklikheidskepping behels (Strand, 1997:338). Hierteenoor behels 'n modernistiese paradigma dat die terapeut die alleenkundige van die kliënt se probleem is. Daar word as't ware vir die kliënt 'n voorskrif gegee waarvolgens geleef moet word. 'n Persoon sal byvoorbeeld as 'n alkoholis gediagnoseer word, wat hom in die posisie plaas waar soos 'n alkoholis opgetree word. Geen geleentheid word dus vir 'n herformulering van dié werklikheid geskep nie. 'n Nie-kundige posisie impliseer egter nie dat enige persoon 'n fasiliteerder kan wees nie. Gespesialiseerde kennis is nodig om die kliënt na nuwe betekenisgewing van sy werklikheid te lei (Laird, 1993:89). Tereg noem Ferreira en Botha (1999:84) dat die fasiliteerder 'n gesprekskunstenaar is wat die gesprek aan die gang hou. Die kliënt word dus gesien as die kenner van sy situasie en daar word aangeneem dat hy oor die nodige kennis beskik om alternatiewe te vind.

Die verhouding tussen die fasiliteerder en die kliënt word derhalwe deur samewerking en vennootskap gekenmerk. Die fasiliteerder sal byvoorbeeld idees tentatief aanbied, maar dit nie op die kliënt afdwing nie, aangesien daar 'n verhouding van respek, empatie en aanvaarding bestaan (Ferreira \& Botha, 1999:85). Freedman en Combs (1996:45) is van mening dat die meeste sukses in die nie-kundige posisie behaal word wanneer daarop gekonsentreer word om te luister na wat gesê word. Tydens die luisterproses behoort fasiliteerders hulle af te vra of verstaan word hoe dit voel om in die kliënt se posisie te wees, en of hulle nie bloot besig is om gapings van die storie met eie aannames in te vul nie. Die rigtinggewende denkwyse behoort dit te wees wat die fasiliteerder moet weet om as't ware in die kliënt se skoene in te klim.

Nog 'n eienskap van hierdie posisie is dat dit nuuskierigheid bevorder. Die fasiliteerder raak nuuskierig na aanleiding van die kliënt se unieke antwoorde en laasgenoemde word gemotiveer om op antwoorde uit te brei. Freedman en Combs (1996:45) sê: "[j]ust listening and asking facilitating and clarifying questions from a position of curiosity, can be very therapeutic." Die rede hiervoor is waarskynlik dat kliënte die geleentheid kry om die situasie los van hulself te sien, wat tot die skep van 'n nuwe narratief aanleiding kan gee.

\section{Deursigtigheid}

Die doel met deursigtigheid is om respek tydens die terapeutiese proses te betoon. Die terapeut se agenda is nie onbekend aan kliënte nie; die terapeut is ' $n$ vennoot in die proses van hul rehabilitasie (Du Plessis, 2000:133). So byvoorbeeld sal verslagskrywing ten opsigte van inligting wat kliënte oordra, in oorleg met kliënte plaasvind. Hulle is medewerkers in die skryf van die verslae. Dit gebeur selfs dat kliënte afskrifte van verslae tuis hou (White, 1995:47). Indien kliënte die verslae self analiseer en help skryf, kan dit help met die herskryf van die eie verhaal, aangesien die verhaal meer objektief beleef word. Wanneer van hierdie werkswyse gebruik gemaak word, behoort die terapeut versigtig te wees om die kliënt nie te etiketteer nie, aangesien dit die terapeutiese proses kan benadeel en die kliënte kan ontmagtig. Dieselfde geld wanneer daar met 'n gemeenskap gewerk word. Hoewel alle inligting vertroulik hanteer word, behoort die aksiekomitee die inhoud daarvan te analiseer. Die aksiekomitee word dan die skrywers van 'n nuwe gemeenskapsverhaal.

Wanneer die kliënt met 'n ander terapeut bespreek moet word, behoort dit in die teenwoordigheid van die kliënt plaas te vind om deursigtigheid te verseker (Lax, 1992:80). Hier is die doel die identifisering van unieke uitkomste en fasilitering van die herskryf van die dominante storie. 
Uiteraard kan die gebruik soms moeilik toegepas word, aangesien 'n ander terapeut nie altyd tydens 'n terapeutiese gesprek beskikbaar kan wees nie. Binne die konteks van gemeenskapsontwikkeling kan dit beteken dat die gemeenskap nie met 'n ander ontwikkelaar bespreek word sonder dat die aksiekomitee of lede van die komitee teenwoordig is nie. Tydens die gesprek(ke) kan die identifisering van unieke uitkomste en wysigings aan die gemeenskap se dominante storie gefasiliteer word.

Emosionele deursigtigheid is ook van belang. In die terapeutiese proses poog terapeute nie om hul emosies weg te steek nie, maar kan hulle saam met die kliënt lag en huil (White, 1995:86). Sommige terapeute kan dit moeilik vind om op hierdie wyse deursigtigheid te openbaar, aangesien nie almal gemaklik voel om hulle emosies met ander te deel nie. 'n Eie interpretasie is dat hierdie 'n element van deursigtigheid is waarmee terapeute eers persoonlik vrede moet maak voordat dit benut word. Indien die terapeut ongemaklik voel om sy emosies te deel, kan dit moontlik die totale ontwikkelingsproses benadeel.

'n Deursigtige werkswyse blyk derhalwe die voordeel in te hou dat die kliënt 'n groter aandeel in die proses het, dat geen geheime bestaan nie en dat die terapeut sy emosies aan die kliënt openbaar. Deursigtigheid dra dus by tot die bou van 'n vertrouensverhouding tussen die betrokkenes. Die gemeenskap behoort altyd te beleef dat die ontwikkelaar alles tot voordeel van die gemeenskap doen. Uit eie praktykervaring, kan dié punt met 'n voorbeeld verduidelik word. By 'n steenmakeryprojek is geld vanaf verskillende borge verkry. Die wyse waarop die geld bekom is, vereis van die ontwikkelaar dat hy met behulp van die finansiële stelsel van die Universiteit van die Vrystaat, hierdie projek se finansiële bestuur doen. Die persone wat deel van die projek uitmaak, is ongeletterd en dus nie in staat tot formele finansiële bestuur nie. Die konsepte van wins en verlies is by talle geleenthede aan die betrokkenes verduidelik, waartydens onder andere van 'n tolk (die gemeenskap se burgemeester) en Sesotho-sprekende maatskaplikewerkstudente gebruik gemaak is. Dit blyk egter dat gemeenskapslede die mening handhaaf dat die ontwikkelaar finansieel by die projek baat en fondse vir homself neem. Klaarblyklik was die proses nie deursigtig genoeg nie. Oënskynlik behoort alle rekords aan iemand wat die mense vertrou, beskikbaar gestel te word, sodat hulle hulself van die feite kan vergewis. Die gemeenskap behoort ook in 'n posisie geplaas te word waarin hulle 'n groter aandeel in die finansiële bestuur van die projek het. Tans word aandag hieraan geskenk.

\section{Medewerksaamheid}

Medewerksaamheid impliseer dat sowel die terapeut as die kliënt verantwoordelikheid vir die hantering van die situasie aanvaar. Sodoende word die terapeut nie as kenner belas met die verantwoordelikheid om die kliënt se situasie te verander nie. Die kanse vir uitbranding aan die kant van die terapeut word dus verminder (White, 1997:193-199). Medewerksaamheid hou dus potensiaal in vir selfbemagtiging deur die kliënt. Die kliënt kry 'n greep op sy situasie en wanneer dit bestuur word, is die belewenis van sukses groter, aangesien dit nie net die terapeut was wat al die insette gelewer het nie. Die implementering van hierdie beginsel impliseer voorts ' $n$ spanbenadering, want die situasie word in vennootskap tussen die kliënt en terapeut hanteer.

'n Eie interpretasie is dat die beginsels met vrug met die oog op selfbemagtiging tydens gemeenskapsontwikkeling benut kan word. Wanneer die gemeenskap kundiges van hulle situasie gemaak word, raak hulle nie afhanklik van die ontwikkelaar nie. Hulle is ook self verantwoordelik vir die herformulering van die dominante storie waarvolgens hulle leef. Wanneer hulle die storie self verander en daarvolgens leef, realiseer selfbemagtiging. 'n Dominante storie soos ek is sleg, kan dan verander na een van slegte dinge het met my gebeur. 
Medewerksaamheid hang ten nouste saam met die beginsels van selfwerksaamheid en deursigtigheid. Wanneer die gemeenskap self verantwoordelikheid vir hulle omstandighede neem, word hulle in werklikheid in 'n selfbemagtigingsposisie geplaas. Eie praktykervaring hiervan is gevind in ' $n$ gemeenskap waar ' $n$ behoefte aan ' $n$ meerdoelige sentrum vir projekte en opleiding geïdentifiseer is. Na etlike jare se harde werk deur die ontwikkelaar en sommige gemeenskapslede is 'n meerdoelige sentrum gebou. Die sentrum bestaan uit 'n lokaal wat vir vergaderings en opleiding benut word, 'n tweede gebou wat vier projekte huisves asook 'n kleuterskool. Die basiese bestuur vir die sentrum is aan die plaaslike ontwikkelingsforum toegeken. Alle probleme wat by die ontwikkelaar aangemeld word, word na die forum verwys. Aanvanklik is die ontwikkelaar gereeld genader om die situasies te hanteer. Weens die handhawing van die medewerksaamheidsbeginsel het die ontwikkelaar die gemeenskap konstant gevra wat hul mening oor die situasies is. Dit was opmerklik dat daar vir al die gevalle oplossings gevind is sonder veel fasilitering deur die ontwikkelaar. Waarskynlik weens die sterk klem op medewerksaamheid, selfwerksaamheid en deursigtigheid is die gemeenskap besig om toenemend onafhanklik van die ontwikkelaar te funksioneer.

\section{SAMEVATTING}

Tydens gemeenskapsontwikkeling is een van die belangrikste take van 'n maatskaplike werker die motivering van die gemeenskap om aan eie ontwikkeling deel te neem. Meesal word primêr aandag aan die oordrag van vaardighede geskenk, terwyl gemeenskappe dikwels nie oor genoegsame motivering beskik om volhoubaar aan ontwikkelingsprojekte deel te neem nie. Die benutting van ' $n$ narratiewe benadering kan daartoe bydra om so 'n motiveringsgebrek te bowe te kom.

Die waarde van die narratiewe benadering is daarin geleë dat met mense se ervarings en hul persepsie van daardie ervarings gewerk word. Werklikheidskepping kan daartoe aanleiding gee dat gemeenskappe se eiewaarde laag is. Hulle behoort gehelp te word om hierdie werklikhede te verander en hulself as waardevol te ag. Ten einde selfwaardering te kweek, word van die narratiewe werkswyse gebruik gemaak. Taal word gebruik om 'n ryker beskrywing van die gemeenskap se werklikheid te skep. Die werklikheid word op so 'n wyse herkonstrueer dat gemeenskapslede 'n gevoel van bemagtiging ervaar.

Die maatskaplike werker sal gedurende die kontak met die gemeenskap 'n nie-kundige posisie inneem. Dit beteken dat die gemeenskap die geleentheid gegun word om vanuit 'n eie werklikheid hulself en hul omgewing te herinterpreteer en te herstruktureer. Gedurende die proses word deursigtigheid en medewerksaamheid beklemtoon. Die gemeenskap kry die geleentheid om verantwoordelikheid vir hulle eie situasie te aanvaar. Wanneer 'n greep op die situasie verkry word, voel hulle meer in beheer en kan hulle oorgaan tot verdere aksies wat hulle selfontwikkeling en dié van hul gemeenskap kan bevorder. Hierdie aksies kan projekte insluit wat gerig is op ekonomiese, fisiese, psigiese en emosionele ontwikkeling, met selfbemagtiging as uiteindelike resultaat.

\section{BIBLIOGRAFIE}

BURCK, C. \& DANIEL, G. 1995. Gender and family therapy. London. Karnac.

DEAN, R.G. 1993. Constructivism: An approach to clinical practice. Smith College Studies in Social Work, 36(2):127-145.

DICKERSON, V.C. \& ZIMMERMAN, J.L. 1996. Myths, misconceptions, and a word or two about politics. Journal of Systemic Therapies, 15(1):79-88. 
DU PLESSIS, M.J.M. 2000. Die ontwerp van 'n gemeenskapsontwikkelingsmodel: 'n maatskaplikewerk-perspektief. Bloemfontein: Universiteit van die Oranje-Vrystaat. (D.Phil.proefskrif)

DU PLESSIS, M.J.M. \& FERREIRA, S.B. 2000. Konstruktivisme, konstruksionisme en maatskaplike werk. Koers, 65(1):17-44.

EPSTON, D. 1998. Catching up with David Epston: a collection of narrative practice-based papers published between 1991 and 1996. South Australia: Dulwich.

EPSTON, D.; WHITE, M. \& MURRAY, K. 1992. A proposal for re-authoring therapy: Rose's revisioning of her life and a commentary. In: McNAMEE, S. \& GERGEN, K.J. (eds) Therapy as social construction. Newbury Park: Sage.

FERREIRA, S.B. \& BOTHA, D. 1999. 'n Sosiaal-konstruktivistiese benadering in maatskaplike werk: Die stories waarvolgens gesinne leef. Maatskaplikewerk-Navorser-Praktisyn, 11(1):7894.

FREEDMAN, J. \& COMBS, G. 1996. Narrative therapy: The social construction of preferred realities. New York: Norton.

GERGEN, K.J. 1994. Realities and relationships: Soundings in social construction. Cambridge: Harvard.

GREENE, G.J., JENSEN, C. \& JONES, D.H. 1996. A constructivist perspective on clinical social work practice with ethnically diverse clients. Social Work, 41(2):172-180.

HAWKINS, J.M. 1988. The Oxford paperback dictionary. Oxford: Oxford University Press.

HOLLAND, T.P. \& KILPATRICK, A.C. 1993. Using narrative techniques to enhance multicultural practice. Journal of Social Work Education, 29(3):302-308.

JANKOWSKI, P.J. 1998. A developmental-constructivist framework for narrative therapy. Family Therapy, 25(2):111-120.

JANSE VAN RENSBURG, J. 2000. The paradigm shift. An introduction to postmodern thought and its implications for theology. Pretoria: Van Schaik.

LAIRD, J. 1993. Family-centered practice: cultural and constructionist reflections. Journal of Teaching in Social Work, 8(1/2):77-109.

LAX, W.D. 1992. Postmodern thinking in a clinical practice. In: McNAMEE, S. \& GERGEN, K.J. (eds) Therapy as social construction. London: Sage.

LOEVLIE, L. 1992. Postmodernism and subjectivity. In: KVALE, S. (ed) Psychology and postmodernism. London: Sage.

MAGADLA, L. 1996. Constructivism: a practitioner's perspective. South African journal for higher education, 10(1):83-88.

MIDGLEY, J. 1996. The developmental perspective in social welfare: Transcending residual and institutional models. Social Work Practice 1:2-8.

MORTOLA, P. 1999. Narrative formulation and gestalt closure: Helping clients make sense of "disequilibrium" through stories in the therapeutic setting. (Unpublished article, in researcher's possession)

MÜLLER, J. 1996. Om tot verhaal te kom: pastorale gesinsterapie. Pretoria: RGN. 
NEAL, J.H. 1996. Narrative therapy training and supervision. Journal of Systematic Therapies, 15(1):63-67.

PARRY, A. 1991. A universe of stories. Family Process, 30:30-37.

PARRY, A. \& DOAN, R. 1994. Story re-visions: Narrative therapy in the postmodern world. New York: Guilford.

REYNEKE, R.P. 2000. 'n Narratiewe Maatskaplikewerkbenadering vir gemeenskapsbemagtiging. Bloemfontein: Universiteit van die Oranje-Vrystaat. (D.Phil proefskrif).

ROBBINS, A. 1992. Awaken the giant within. New York: Simon and Schuster.

SEIDMAN, S. 1994. Contested knowledge: social theory in the postmodern era. Oxford: Blackwell.

SHAW, A. 1996. Social construction and the inner city: Designing environments for social development and urban renewal. In: KAFAI, Y. \& RESNICK, M. (eds) Constructionism in practice - designing, thinking, and learning in a digital world. New Jersey: Lawrence Erlbaum.

SLUZKI, C.E. 1992. Transformations: a blueprint for narrative changes in therapy. Family Process, 31:217-230.

STRAND, P.S. 1997. Toward a developmentally informed narrative therapy. Family Process, 36(2):325-339.

VAN DER BERG, C.; COLLINS, K. \& O’NEIL, M.A. 1999. Die gemeenskapswerker en taalkonstruktivisme in die fase van behoeftebepaling. Social Work/Maatskaplike Werk, 35(2):113123.

VAN NIEKERK, G. 1999. Motivering (1): Ontwikkel jou innerlike sterkte. Landbouweekblad, 1103:27.

VON GLASSERSFELD, E. 1984. An introduction to radical constructivism. In: WATZLAWICK, P. (ed) The invented reality. New York: Norton.

VON GLASSERSFELD, E. 1995. Radical constructivism: a way of knowing and learning. London: Falmer.

WEINGARTEN, K. 1998. The small and the ordinary: The daily practice of a postmodern narrative therapy. Family Process, 37(Spring):3-15.

WHITE, C. \& DENBOROUGH, D. 1998. Introducing narrative therapy. A collection of practice-based writings. Adelaide: Dulwich.

WHITE, M. 1993. Deconstruction and therapy. In: GILliGAN, S. \& PRICE, R. (eds) Therapeutic conversations. New York: Norton.

WHITE, M. 1995. Re-authoring lives: interviews and essays. Adelaide: Dulwich.

WHITE, M. 1997. Narratives of therapists' lives. Adelaide: Dulwich Centre.

WHITE, M. \& EPSTON, D. 1990. Narrative means to therapeutic ends. New York: Norton.

ZIETSMAN, A. 1996. Constructivism: super theory for all education ills? South African Journal for Higher Education, 10(1):70-75. 